\title{
Performance and Muscular Development of Nile Tilapia Larvae (Oreochromis niloticus) Fed Increasing Concentrations of Phenylalanine
}

\author{
Diogo Yamashiro1, Dacley Hertes Neu², Evandro Bilha Moro ${ }^{3}$, Aldi Feiden ${ }^{3}$, Altevir Signor ${ }^{3}$, \\ Wilson Rogério Boscolo ${ }^{3}$, Fábio Bittencourt ${ }^{3 *}$ \\ ${ }^{1}$ Cooperativa Agroindustrial Consolata, Nova Aurora, Brazil \\ ${ }^{2}$ Faculdade de Ciências Agrarias-FCA, Universidade Federal da Grande Dourados, Dourados, Brazil \\ ${ }^{3}$ Centro de Engenharias e Ciências Exatas, Universidade Estadual do Oeste do Paraná, Toledo, Brazil \\ Email: ^fabio.gemaq@gmail.com
}

How to cite this paper: Yamashiro, D., Neu, D.H., Moro, E.B., Feiden, A., Signor, A., Boscolo, W.R. and Bittencourt, F. (2016) Performance and Muscular Development of Nile Tilapia Larvae (Oreochromis niloticus) Fed Increasing Concentrations of Phenylalanine. Agricultural Sciences, 7, 900-910. http://dx.doi.org/10.4236/as.2016.712081

Received: November 29, 2016 Accepted: December 26, 2016 Published: December 29, 2016

Copyright $\odot 2016$ by authors and Scientific Research Publishing Inc. This work is licensed under the Creative Commons Attribution International License (CC BY 4.0).

http://creativecommons.org/licenses/by/4.0/

\begin{abstract}
Even though tilapia is of great economic interest, data on the nutritional requirements of amino acids during commercial breeding stages are scarce. So, the aim of this study was to analyse the performance and muscular growth of Nile tilapia larvae (Oreochromis niloticus) fed diets containing increasing concentrations of phenylalanine. The experiment took place at the Laboratory of Aquaculture of the Grupo de Estudos de Manejo na Aquicultura (GEMAq) of the Universidade Estadual do Oeste do Paraná (Unioeste), Toledo, PR, Brazil, for 30 days. A total of 450 larvae, with mean initial length of $1.5 \pm 0.14 \mathrm{~cm}$ and mean initial weight of $0.04 \pm 0.004 \mathrm{~g}$, were randomly distributed into 6 treatment groups with 5 repetitions (30 tanks). Each experimental unit consisted of a $30 \mathrm{~L}$ tank containing 15 larvae. Six diets were formulated with increasing concentrations of phenylalanine $(1.09,1.24,1.39,1.54,1.69$ and $1.84 \%$ ) and offered four times a day until apparent satiation. By the end of the experimental period, the following productivity indexes were analysed: length, weight, survival, weight gain, uniformity, feed conversion, specific growth rate and protein efficiency ratio. Three fish from each tank were collected for muscular growth analysis and the frequency of small $(<20 \mu \mathrm{m}$ in diameter $)$ and large $(20-50 \mu \mathrm{m})$ muscle fibres recorded. Small fibres corresponded to $60 \%-90 \%$ of the fibres observed, suggesting that muscular growth at this stage occurred mainly by hyperplasia. No significant difference $(\mathrm{P}>0.05)$ was observed in the productive performance parameters between the treatment groups. Thus, it can be concluded that the levels of phenylalanine contained in the experimental diets did not influence the performance of Nile tilapia larvae. However, there was more hyperplasia when we put $1.39 \%$ of phenylalanine in the diet.
\end{abstract}




\section{Keywords}

Amino Acids, Amino Acid Requirements, Larval Fish Nutrition

\section{Introduction}

The Nile tilapia (Oreochromis niloticus) is one of the fresh water species with the greatest technological package due to its rusticity, climate adaptation, prolificacy and excellent flesh quality [1]. Thus, the farming of this species has been growing and approximately 169.453 thousand tonnes of Nile tilapia were produced in Brazil in 2013 [2].

Studies aimed at increasing productivity while reducing production costs often use plant proteins to replace those of animal origin [3] [4] or include by-products of processing industries [5]. In recent years, the addition of amino acids to fish diets has proven popular and new information on their effects and requirements has been detailed.

In general, fish does not have protein requirements per-se but needs a balance between essential and non-essential amino acids [6], which must be present in adequate quantities and ratios or be supplemented in their synthetic form in the feed [7]. Like all other animals, fish requires ten essential amino acids in their diet: arginine, phenylalanine, histadine, isoleucine, lysine, methionine, threonine, tryptophan and valine, out of which lysine and methionine are the most limiting [8].

Santiago and Lovell [9] established the phenylalanine + tyrosine requirement of Nile tilapia larvae to be $1.05 \%$ of the diet or $3.75 \%$ of the protein content. Based on the essential amino acid: digestible lysine ratio, Furuya [10] estimated the requirement of phenylalanine + tyrosine to be $2.38 \%$ for the sexual inversion phase, $1.65 \%$ for fish up to $100 \mathrm{~g}$ of live weight and $1.50 \%$ for those above $100 \mathrm{~g}$ of live weight. However, more information can help to determine the best supplementation levels of these amino acids in each phase of development.

Phenylalanine is an aromatic amino acid and its requirement is influenced by the concentration of tyrosine in the diet. Phenylalanine is the sole precursor of tyrosine, which in turn is the precursor of T3 (triiodothyronine) and T4 (thyroxine) hormones that are essential for normal metabolic processes and growth [11]. The NRC [12] highlights that the aromatic amino acid requirements of salmon, channel catfish, common carp and Japanese eel are 5.1\%, 5.0\%, 6.5\% and 5.8\% of the protein, respectively.

Even though tilapia is of great economic interest, data on the nutritional requirements of amino acids during commercial breeding stages are scarce. Great economic losses could result if these requirements were to be based only in relation to what is found in the fillet, as these requirements might vary with each stage of development.

Studies aimed at determining the percentage of essential amino acids inclusion in the diet of Nile tilapia are of great importance for the development of a balanced diet that 
provides sufficient nutrients for successful fish production. Thus, the aim of this study was to analyse the influence of phenylalanine on the productive performance and muscular growth of Nile tilapia larvae (Oreochromis niloticus).

\section{Materials and Methods}

The experiment took place at the Laboratory of Aquaculture of the Grupo de Estudos de Manejo na Aquicultura (GEMAq), Universidade Estadual do Oeste do Paraná (Unioeste), Toledo-PR, Brazil. The experiment lasted for 30 days and was approved by the Ethics Committee on the Use of Animals for Research (protocol number 24/2014).

Four hundred and fifty Nile tilapia larvae were used in this study. The larvae had mean initial length and weight of $1.5 \pm 0.14 \mathrm{~cm}$ and $0.04 \pm 0.004 \mathrm{~g}$, respectively. The fish were randomly distributed into six treatments groups with five repetitions and placed into thirty 30L tanks containing 15 fish each (experimental unit). The tanks were individually equipped with a constant aeration system and syphoned twice daily (40\% of aquarium volume) before the first and after the last feed, in order to remove leftover food and residues from fish excretion.

Six diets were formulated with increasing concentrations of phenylalanine: 1.09, $1.24,1.39,1.54,1.69$ and 1.84\% (Table 1), based on Furuya [10]. The ingredients used were selected according to the quantity of phenylalanine in their composition [13] and ground using a hammer mill with $0.5 \mathrm{~mm}$ in diameter screen holes. The ground ingredients were weighed, homogenized, humidified and extruded using an extrusion equipment (Ex-Micro ${ }^{\circledR}$ extruder, ExTeec Company, Ribeirão Preto, Brazil). Subsequently, they were dried in a kiln (TE-394/3, Tecnal, Piracicaba, Brazil) by forced ventilation for 72 hours at $55^{\circ} \mathrm{C}$. The pellets were ground in order to obtain a meal ration and alpha-methyl-testosterone $(60 \mathrm{mg} / \mathrm{kg}$ of feed) added to finalize larval sexual inversion. Fish were fed four times a day at 8:00 hr, 11:00 hr, 14:00 hr and 17:00 hr until apparent satiation.

The physical and chemical parameters of the water, such as $\mathrm{pH}$ (7.3) and dissolved oxygen $\left(4.32 \mathrm{mg} \cdot \mathrm{L}^{-1}\right)$, were measured weekly using a multi-parameter digital equipment (YSI $\left.{ }^{\oplus}\right)$ and the temperature $\left(24.2^{\circ} \mathrm{C} \pm 1.5^{\circ} \mathrm{C}\right)$ recorded daily.

At the end of the experiment, food was withheld for 24 hours to allow empting of the digestive tract. The fish were removed from the tanks, desensitized with benzocaine (ethyl-aminobenzoate) at $240 \mathrm{mg} \cdot \mathrm{L}^{-1}$ of water, according to the protocol by Okamura et al. [14], and subsequently euthanized.

The productivity indexes analysed were: final length $(\mathrm{cm})$, final weight $(\mathrm{g})$, survival rate (\%), weight gain (g), specific growth rate (SGR), feed conversion (FCR), protein efficiency rate (weight gain/consumed protein) (\%) and uniformity (\%). The survival (Sur) (1), SGR (2) and FCR (3) rates were calculated using the following equations:

$$
\operatorname{Sur}(\%)=\left(\frac{n f}{n i}\right) \times 100
$$


Table 1. Percentage and nutritional composition of the diets containing increasing concentrations of phenylalanine fed to Nile tilapia larvae (Oreochromis niloticus).

\begin{tabular}{|c|c|c|c|c|c|c|}
\hline \multirow{2}{*}{ Ingredient (\%) } & \multicolumn{6}{|c|}{ Phenylalanine concentration (\%) } \\
\hline & 1.09 & 1.24 & 1.39 & 1.54 & 1.69 & 1.84 \\
\hline Meat and bone meal & 26.23 & 26.23 & 26.23 & 26.23 & 26.23 & 26.23 \\
\hline Fishmeal & 24.90 & 24.90 & 24.90 & 24.90 & 24.90 & 24.90 \\
\hline Wheat Bran & 23.75 & 23.75 & 23.75 & 23.75 & 23.75 & 23.75 \\
\hline L. Alanine & 7.50 & 7.40 & 7.29 & 7.19 & 7.08 & 6.98 \\
\hline L. Glutamic Acid & 7.50 & 7.55 & 7.60 & 7.65 & 7.70 & 7.75 \\
\hline Soybean oil & 6.88 & 6.78 & 6.68 & 6.58 & 6.48 & 6.39 \\
\hline Premix $^{\mathrm{a}}$ & 1.00 & 1.00 & 1.00 & 1.00 & 1.00 & 1.00 \\
\hline L-lysine & 0.79 & 0.79 & 0.79 & 0.79 & 0.79 & 0.79 \\
\hline L-threonine & 0.63 & 0.63 & 0.63 & 0.63 & 0.63 & 0.63 \\
\hline Salt & 0.30 & 0.30 & 0.30 & 0.30 & 0.30 & 0.30 \\
\hline L-tryptophan & 0.21 & 0.21 & 0.21 & 0.21 & 0.21 & 0.21 \\
\hline DL-methionine & 0.20 & 0.20 & 0.20 & 0.20 & 0.20 & 0.20 \\
\hline Antifungal & 0.10 & 0.10 & 0.10 & 0.10 & 0.10 & 0.10 \\
\hline Antioxidant (BHT) & 0.02 & 0.02 & 0.02 & 0.02 & 0.02 & 0.02 \\
\hline L-phenylalanine & 0.00 & 0.15 & 0.30 & 0.45 & 0.61 & 0.76 \\
\hline \multicolumn{7}{|l|}{ Nutrients (\%) } \\
\hline Linoleic acid & 4.18 & 4.13 & 4.07 & 4.02 & 3.96 & 3.91 \\
\hline Starch & 7.44 & 7.44 & 7.44 & 7.45 & 7.45 & 7.45 \\
\hline Calcium & 4.46 & 4.46 & 4.46 & 4.46 & 4.46 & 4.46 \\
\hline Digestible energy $(\mathrm{Kcal})^{\mathrm{b}}$ & 3,250 & 3,250 & 3,250 & 3,250 & 3,250 & 3,250 \\
\hline Total Phenylalanine & 1.09 & 1.24 & 1.39 & 1.54 & 1.69 & 1.84 \\
\hline Total phenylalanine + tyrosine & 1.89 & 2.04 & 2.19 & 2.34 & 2.49 & 2.64 \\
\hline Total Phosphorus & 2.59 & 2.59 & 2.59 & 2.59 & 2.59 & 2.59 \\
\hline Available phosphorus & 2.50 & 2.50 & 2.50 & 2.50 & 2.50 & 2.50 \\
\hline Fat & 14.29 & 14.19 & 14.09 & 13.40 & 13.90 & 13.80 \\
\hline Lysine & 2.20 & 2.20 & 2.20 & 2.20 & 2.20 & 2.20 \\
\hline Methionine & 0.75 & 0.75 & 0.75 & 0.75 & 0.75 & 0.75 \\
\hline Crude Protein & 42.79 & 42.79 & 42.79 & 42.79 & 42.79 & 42.79 \\
\hline Digestible Protein ${ }^{c}$ & 38.60 & 38.60 & 38.60 & 38.60 & 38.60 & 38.60 \\
\hline Threonine & 1.70 & 1.70 & 1.70 & 1.70 & 1.70 & 1.70 \\
\hline Tryptophan & 0.43 & 0.43 & 0.43 & 0.43 & 0.43 & 0.43 \\
\hline
\end{tabular}

Based on the concentrations recommended by Furuya [10]; The diet was formulated with the assistance of software Supercrac (TD Software, Viçosa, MG, Brazil); ${ }^{a}$ Nutrition facts (minimum): Vitamin A = 1,000,000 UI/kg; Vitamin D3 = 500,000 UI $/ \mathrm{kg}$; Vitamin E = 20,000 UI $/ \mathrm{kg}$; Vitamin K3 = $500 \mathrm{mg} / \mathrm{kg}$; Vitamin B1 = 1,900 mg $/ \mathrm{kg}$; Vitamin B2 = $2000 \mathrm{mg} / \mathrm{kg}$; Vitamin B6 = $2400 \mathrm{mg} / \mathrm{kg}$; Vitamin B12 $=3500 \mathrm{mcg} / \mathrm{kg} ;$ Vitamin C $=25 \mathrm{~g} / \mathrm{kg}$; Niacin = 5,000 mg/kg; Pantothenic acid $=4800 \mathrm{mg} / \mathrm{kg}$; Folic acid $=200 \mathrm{mg} / \mathrm{kg}$; Biotin $=40 \mathrm{mg} / \mathrm{kg} ;$ Manganese $=7500 \mathrm{mg} / \mathrm{kg} ;$ Zinc $=25.0$ $\mathrm{g} / \mathrm{kg}$; Iron $=12.50 \mathrm{~g} / \mathrm{kg}$; Copper $=2000 \mathrm{mg} / \mathrm{kg}$; Iodine $=200 \mathrm{mg} / \mathrm{kg}$; Selenium $=70 \mathrm{mg} / \mathrm{kg}$; ${ }^{\mathrm{b}} \mathrm{Level}$ of digestible energy recommended by Boscolo et al. [15]; 'Level of digestible protein recommended by Hayashi et al. [16]. 


$$
\begin{gathered}
\operatorname{SGR}(\% \text { day })=\left(\frac{\ln w f-\ln w i}{t}\right) \times 100 \\
F C R=\frac{F I}{W G}
\end{gathered}
$$

where $n f=$ number of fish in the tanks at the end of the experiment; $n i=$ number of fish at the start of the experiment; $w f=$ final weight $(\mathrm{g})$; $w i=$ initial weight $(\mathrm{g}) ; t=$ length of experiment (days); $F I=$ feed intake (g); $W G=$ weight gain (g).

Three fish from each tank were used to analyse muscular growth. A vertical sample (dorso-ventral) was removed with the aid of a blade and fixed in $10 \%$ buffered formalin containing a descaler, for 24 hours, prior to paraffin embedding. Transversal sections ( 6 $\mu \mathrm{m})$ were stained with haematoxylin-eosin and a system of image analysis used for morphometry (Image-Pro Plus), in which the smallest diameter of the muscle fibres was determined. A total of 200 muscle fibres were analysed per animal and then classified according to their diameter $(<20 \mu \mathrm{m}$ or $20-50 \mu \mathrm{m})$ in order to determine the contribution of hyperplasia and hypertrophy to muscular growth [17]. These analysis took place at the Laboratory of Histology of the Grupo de Estudos de Manejo na Aquicultura (GEMAq), Universidade Estadual do Oeste do Paraná (Unioeste), Toledo, PR, Brazil. The data was ranked $(<20 \mu \mathrm{m})$ and logarithmized $(20-50 \mu \mathrm{m})$ so that parametric analysis could be applied.

Statistical analysis was performed by ANOVA followed by Tukey test using the programme Statistic "Statistic 7.1" [18]. Significance was considered at 5\%.

\section{Results}

No significant difference $(\mathrm{P}>0.05)$ was observed in mean final length $(\mathrm{MFL})$, mean final weight (MFW), survival rate (Sur), weight gain (WG), specific growth rate (SGR), uniformity (Unif) or feed conversion (FCR) (Table 2).

Table 2. Productive performance of Nile tilapia larvae fed diets containing increasing concentrations of phenylalanine.

\begin{tabular}{ccccccc}
\hline \multicolumn{7}{c}{ Phenylalanine concentration (\%) } \\
\hline Variables $^{\mathrm{a}, \mathrm{b}}$ & 1.09 & 1.24 & 1.39 & 1.54 & 1.69 & 1.84 \\
MFW (g) & $0.70 \pm 0.03$ & $0.73 \pm 0.26$ & $0.70 \pm 0.07$ & $0.81 \pm 0.23$ & $0.77 \pm 0.18$ & $0.86 \pm 0.16$ \\
MFL (cm) & $3.40 \pm 0.15$ & $3.54 \pm 0.32$ & $3.36 \pm 0.14$ & $3.49 \pm 0.28$ & $3.64 \pm 0.31$ & $3.57 \pm 0.26$ \\
WG (g) & $0.64 \pm 0.03$ & $0.66 \pm 0.26$ & $0.64 \pm 0.06$ & $0.74 \pm 0.23$ & $0.70 \pm 0.18$ & $0.79 \pm 0.16$ \\
FCR & $1.93 \pm 1.28$ & $3.01 \pm 1.15$ & $1.72 \pm 0.69$ & $2.01 \pm 0.35$ & $2.05 \pm 1.55$ & $1.67 \pm 0.19$ \\
Sur (\%) & $75.00 \pm 24.49$ & $65.00 \pm 16.60$ & $85.00 \pm 22.41$ & $66.67 \pm 10.54$ & $57.33 \pm 25.65$ & $73.33 \pm 20.00$ \\
Unif (\%) & $60.75 \pm 11.00$ & $79.60 \pm 10.33$ & $76.60 \pm 10.88$ & $71.50 \pm 16.93$ & $82.62 \pm 19.27$ & $73.12 \pm 12.20$ \\
SGR & $7.96 \pm 0.26$ & $8.63 \pm 1.16$ & $7.81 \pm 0.29$ & $8.22 \pm 0.91$ & $8.09 \pm 0.52$ & $8.56 \pm 0.73$ \\
PER (\%) & $3.17 \pm 3.04$ & $5.53 \pm 2.42$ & $2.78 \pm 1.38$ & $3.28 \pm 0.64$ & $3.42 \pm 3.89$ & $2.80 \pm 0.32$ \\
\hline
\end{tabular}

${ }^{a}$ Data is presented as mean \pm standard deviation; final weight (FW); mean final length (MFL); weight gain (WG) = final weight-initial weight; survival (Sur) $=100$ (final number of fish/initial number of fish); specific growth rate $(\mathrm{SGR})=100 *(($ ln final weight-ln initial weight $) /$ experimental days $)$; feed conversion $(\mathrm{FCR})=$ diet consumed $/$ weight gain; protein efficiency rate $(\mathrm{PER})=($ weight gain/protein consumed $)$; Uniformity $($ Unif $)=100 *$ (number of fish with body weight within the mean \pm standard deviation /total number of fish); ${ }^{b}$ No significant difference $(P>0.05)$. 
Muscle fibres with diameter smaller than $20 \mu \mathrm{m}$ corresponded to $60 \%-90 \%$ of the fibres observed while those with diameter between $20-50 \mu \mathrm{m}$ corresponded only to $10 \%-40 \%$ (Table 3 ).

\section{Discussion}

The lack of significant differences in the productive performance parameters of the larvae fed diets containing increasing concentrations of phenylalanine is probably due to the fact that the amino acid requirements for this stage of development was met by the diet with the lowest concentration of phenylalanine tested (1.09\%). Santiago and Lovell [9] established the requirement of phenylalanine by Nile tilapia larvae to be $1.05 \%$ of phenylalanine + tyrosine; however, these authors used purified diets while the diets used in the current study were semi-purified.

Furuya [10] stated that diets for Nile tilapia at the sexual inversion stage must contain $2.38 \%$ phenylalanine + tyrosine. In the present study, the concentrations of phenylalanine + tyrosine used were $1.89 \%, 2.04 \%, 2.19 \%, 2.34 \%, 2.49 \%$ and $2.69 \%$; and the lowest concentration of both amino acids did not cause loss in the performance of larval stage. However, differently from the study by Furuya [10], the present study used dose-response testing, which explains the results obtained.

Borlogan [19], when determining the requirements of phenylalanine + tyrosine by juvenile "milkfish" (Chanos chanos), obtained better weight gain results with diets containing 1.3 and $1.2 \%$ of phenylalanine and tyrosine, respectively (phenylalanine + tyrosine $=2.5 \%$ ). This difference to the Nile tilapia can be explained by its feeding habit (omnivore), as carnivore fish have greater amino acid and protein requirements.

Tyrosine is a non-essential amino acid that fish can synthesize from phenylalanine [20]. Thus, when tyrosine is added to the diet it is possible to reduce the concentration of phenylalanine by $40 \%-60 \%$ [12]. In the present study, all diets were formulated to contain levels of tyrosine $(0.8 \%)$ similar to those found in food.

Borlogan [19] states that diets with high concentrations of phenylalanine can be harmful to fish as its accumulation and oxidation generate toxic metabolites and, thus, hinder growth. Furthermore, a good balance of amino acids is required for maximum absorption. An imbalance of amino acids can affect productive performance and cause disproportionate absorption and use of other amino acids [21] [22]. In the present study, productive analysis did not suggest any toxic effect or amino acid imbalance as

Table 3. Frequency of muscle fibre distribution according to their diameter $(<20 \mu \mathrm{m}$ and $20-50$ $\mu \mathrm{m})$ in Nile tilapia larvae fed diets containing increasing concentrations of phenylalanine.

\begin{tabular}{ccccccc}
\hline \multicolumn{5}{c}{ Phenylalanine concentration (\%) } \\
\hline Diameter $^{\mathrm{a}}$ & 1.09 & 1.24 & 1.39 & 1.54 & 1.69 & 1.84 \\
$<20 \mu \mathrm{m}$ & $60.41 \pm 13.02^{\mathrm{b}}$ & $64.16 \pm 4.98^{\mathrm{b}}$ & $80.07 \pm 8.95^{\mathrm{a}}$ & $72.96 \pm 5.89^{\mathrm{ab}}$ & $59.81 \pm 10.77^{\mathrm{b}}$ & $75.02 \pm 11.18^{\mathrm{ab}}$ \\
$20-50 \mu \mathrm{m}$ & $39.59 \pm 13.02^{\mathrm{a}}$ & $35.90 \pm 4.85^{\mathrm{a}}$ & $19.92 \pm 8.95^{\mathrm{b}}$ & $27.04 \pm 5.89^{\mathrm{ab}}$ & $40.35 \pm 10.64^{\mathrm{a}}$ & $29.85 \pm 11.99^{\mathrm{ab}}$ \\
\hline
\end{tabular}

${ }^{a}$ Data is represented as mean \pm standard deviation. Different letters on the same row indicate significant difference $(\mathrm{P}<0.05)$ in the frequency of muscle fibres distribution within a specific diameter. 
there was no significant difference in fish productive performance between the different diets used.

The high feed conversion rate of the present study was probably due to the unrestricted feeding and to the fact that the ration used was ground to a meal after extrusion. High levels of feed conversion (1.9 to 2.6) have also been observed by Ngamsnae et al. [23] in juvenile Bidyanus bidyanus fed diets containing varying concentrations of arginine and phenylalanine and by Ahmed [24] who reported feed conversion levels of 1.34 to 2.42 in a study to determine the requirements of tyrosine and phenylalanine by Cirrhinus mrigala carp larvae. Besides, the diet has been continued be offered until satiation even during the periods when the temperature of water was pleasant.

No significant difference $(\mathrm{P}>0.05)$ was observed in the survival rate of the larvae in the present study. Borlogan and Colosso [25], in a study to determine the amino acid requirements of juvenile "milkfish" (Chanos chanos), observed better survival rates in juveniles fed diets containing high concentrations of phenylalanine $(1.9 \%, 2.20 \%$ and $2.50 \%$ ) and established, through breakpoint equation, $2.8 \%$ as the optimal value to obtain the best survival rates and productive performance indexes. Ngamsnae et al. [23] did not observe any significant difference in the survival rates of juvenile Bidyanus bidyanus, which were similar to the ones obtained in this study. Woynarovich [26] related that can occur mortality from $40 \%$ to $50 \%$ in the early stage of fish life. It can occur due to several factors, one of them is the water temperature that stayed lower than recommended levels.

No significant difference $(\mathrm{P}>0.05)$ was observed in the uniformity of the fish, which may have been due to the favourable conditions the larvae were kept throughout the experiment. Stock density is known to be a determining factor in the uniformity of individuals, thus, the low stock density of the tanks enabled the larvae to be comfortable and have sufficient good quality feed and may have contributed to the uniformity observed. Zaminham [27], in a study with larvae of the same specie fed diets containing increasing concentrations of tryptophan, obtained the best results when higher concentrations of this essential aromatic amino acid were used. Even though phenylalanine is an aromatic amino acid, there are currently no reports on whether it could lead to results similar to those obtained with tryptophan. Nevertheless, as there was no significant difference in uniformity between the treatments in this study, it can be assumed that the diet and environment provided were adequate for the species studied.

The specific growth rate in this study varied from $7.5 \%$ and $9 \%$ a day, similarly to those observed by Bomfim et al. [28] (8.7\%) when diets containing 32\% of crude protein were used. The diets from the current study contained $42 \%$ of crude protein [16], which may have resulted in the higher levels observed. Furthermore, the stage of larval development in which the experiment was conducted is characterized by being the stage with the greatest growth rates in fish.

The protein efficiency rate in this study was relatively high; however, no significant difference $(\mathrm{P}>0.05)$ was observed between the treatments. Furuya et al. [29] reported means of $2.60 \%(30 \% \mathrm{DP})$ to $3.22 \%(25.5 \% \mathrm{DP})$, with rates inversely proportional to the concentration of digestible protein. In the present study, digestible protein corresponded to $38 \%$, 
which may have directly contributed to the results obtained. It is important to note that the diets were formulated to maintain a constant level of the remaining amino acids and only increase the concentration of phenylalanine. Therefore, it can be said that the diets were balanced and that body protein synthesis would only be affected by the concentration of phenylalanine, a fact that was not observed even at the lowest level tested.

Rowlerson and Veggetti [30] determined that high frequency of muscle fibres smaller than $20 \mu \mathrm{m}$ characterized hyperplasia while fibres with diameters greater $50 \mu \mathrm{m}$ characterized hypertrophy. Analysis of the frequency of muscle fibres of different diameters suggest that the muscular development observed in this study occurred mainly by hyperplasia, albeit it seems that hypertrophy may have occurred concomitantly. However, it is possible that muscular development may have occurred only by hyperplasia in mosaic form, in which new muscle fibres originate from the fusion of satellite cells [30] and where small diameter fibres that recently formed around larger ones are notoriously present, as observed in this study.

Aguiar et al. [31] observed that in Nile tilapia the muscle fibres of greater diameter occur in fish that are 90 to 190 days old and that the fries from this species undergo muscular growth by hyperplasia in mosaic form, in accordance with the results obtained in the present study. Jhonston et al. [32] and Zimmerman \& Lowery [33] state that muscular development by hyperplasia is replaced by hypertrophy of the muscular cells when a fish reaches $44 \%$ of its final size; however, this can vary with species. Furthermore, Rowlerson and Veggetti [30] reported that fish have an undetermined growth, which makes it difficult to establish the final weight of an adult.

As well as in our study, Almeida et al. [17] stated that in juvenile Pacu (Piaractus mesopotamicus) muscular development occurs predominantly by hyperplasia. Similarly, Aguiar et al. [34] observed that Nile tilapia larvae fed diets containing increasing concentrations of lysine showed mainly cells smaller than $20 \mu \mathrm{m}$ in diameter, characterizing a predominant development by hyperplasia. These reports are in accordance with the results observed in the current study.

The phenylalanine provides modifications in hyperplasic and hypertrophic muscle growth of the skeletal muscle fibers of tilapia larvae. The higher frequency of fibers with diameter lower than $20 \mu \mathrm{m}$ was observed in fish fed with diet containing $1.39 \%$ of phenylalanine. This result confirm the role of this amino acid in the protein synthesis, however very few studies have analysed the effects of fish nutrition on muscular growth and development and even fewer studies provide information on the effects of phenylalanine on muscular hypertrophy and hyperplasia in fish. Until recently, studies on phenylalanine have focused mainly on its effects as precursor to T3 (triiodotironine) and T4 (thyroxine) hormones, which are required for normal metabolic processes and growth [11]. However, the main response to amino acid consumption is protein synthesis [12], which consequently leads to greater weight gain.

In our study, we verified that the diet containing $1.69 \%$ of phenylalanine resulted in greater frequency of muscle fibres with $20-50 \mu \mathrm{m}$ in diameter, which could be related to the survival rate of this treatment group as it enabled the fish to consume more ra- 
tion than those from the other treatment groups. According to Houlihan [35], muscular tissue growth can result from an increase in the metabolic rate or in the concentration of amino acids available through feeding. However, further studies using dose-response are necessary to determine the effects of phenylalanine for muscle development.

In summary, it was observed that phenylalanine can interfere with the frequency of muscular fibres of different diameters; however, a specific rate could not be determined as the lowest tested level of this amino acid met the nutritional requirements of the Nile tilapia larvae.

\section{Conclusion}

The levels of phenylalanine contained in the experimental diets did not influence the performance of Nile tilapia larvae. However, there was more hyperplasia when we put $1.39 \%$ of phenylalanine in the diet.

\section{References}

[1] Meurer, F., Hayashi, C. and Boscolo, W.R. (2003) Digestibilidade aparente de alguns alimentos proteicos pela tilápia do Nilo (Oreochromis niloticus). Revista Brasileira de Zootecnia, 32, 1801-1809. https://doi.org/10.1590/S1516-35982003000800001

[2] FAO (Food and Agriculture Organization of the United Nations) (2014) Fish Stat. http://www.fao.org

[3] El-Saidy, D.M.S.D. and Gaber, M.M.A. (2002) Complete Replacement of Fish Meal by Soybean Meal with Dietary L-Lysine Supplementation for Nile Tilapia Oreochromis niloticus (L.) Fingerlings. Journal of the World Aquaculture Society, 33, 297-306. https://doi.org/10.1111/j.1749-7345.2002.tb00506.x

[4] Nguyen, T.N., Davis, D.A. and Saoud, I.P. (2009) Evaluation of Alternative Protein Sources to Replace Fish Meal in Practical Diets for Juvenile Tilapia, Oreochromis spp. Journal of the World Aquaculture Society, 40, 113-121. https://doi.org/10.1111/j.1749-7345.2008.00230.x

[5] Boscolo, W.R., Hayashi, C., Feiden, A., Meurer, F. and Signor, A.A. (2008) Composição química e digestibilidade aparente da energia e nutrientes da farinha de resíduos da indústria de filetagem de tilápia, para a tilápia do Nilo (Oreochromis niloticus). Ciência Rural, 38, 2579-2586. https://doi.org/10.1590/S0103-84782008000900027

[6] Wilson, R.P. (1985) Amino Acid and Protein Requirements of Fish. In: Cowey, C.B., Mackie, A.M. and Bell, J.G., Eds., Nutrition and Feeding Fish, Academic Press, London, $1-16$.

[7] Storebakken, T., Shearer, K.D., Baeverfjord, G., Nielsen, B.G., Asgård, T., Scott, T. and De Laporte, A. (2000) Digestibility of Macronutrients, Energy and Amino Acids, Absorption of Elements and Absence of Intestinal Enteritis in Atlantic Salmon, Salmo salar, Fed Diets with Wheat Gluten. Aquaculture, 184, 115-132. https://doi.org/10.1016/S0044-8486(99)00316-6

[8] Wu, G. (2009) Amino Acids: Metabolism, Functions, and Nutrition. Amino Acids, 37, 1-17. https://doi.org/10.1007/s00726-009-0269-0

[9] Santiago, C.B. and Lovell, R.T. (1988) Amino Acid Requirement for Growth of Nile Tilapia. The Journal of Nutrition, 118, 1540-1546.

[10] Furuya, W.M. (2010) Tabelas brasileiras para a nutrição de tilápias. GFM, Toledo, 100 p.

[11] Khan, M.A. and Abidi, S.F. (2007) Total Aromatic Amino Acid Requirement of Indian 
Major Carp Labeo rohita (Hamilton) Fry. Aquaculture, 267, 111-118.

https://doi.org/10.1016/j.aquaculture.2007.02.025

[12] NRC (National Research Concil) (2011) Nutrient Requirements of Fish and Shrimp. National Academies Press, Washington DC.

[13] Rostagno, H. (2011) Tabelas Brasileiras para aves e suínos: Composição de alimentos e exigência nutricional. UFV, Viçosa, 252 p.

[14] Okamura, D., Araújo, F.G., Vieira e Rosa, P., Freitas, R.T.F., Murgas L.D.S. and Cesar, M.P. (2010) Influência da concentração de benzocaína e do comprimento dos peixes na anestesia e na recuperação de tilápias-do-Nilo. Revista Brasileira de Zootecnia, 39, 971-976. https://doi.org/10.1590/S1516-35982010000500005

[15] Boscolo, W.R., Feiden, A., Signor, A., Signor, A.A., Bard, J.J. and Ishida, F.A. (2006) Energia digestível para alevinos de tilápia-do-Nilo (Oreochromis niloticus). Revista Brasileira de Zootecnia, 35, 629-633. https://doi.org/10.1590/S1516-35982006000300001

[16] Hayashi, C., Boscolo, W.R., Soares, C.M. and Meurer, F. (2002) Exigência de proteína digestível para larvas de tilápia do Nilo (Oreochromis niloticus), durante a reversão sexual. Revista Brasileira de Zootecnia, 31, 823-828. https://doi.org/10.1590/S1516-35982002000400003

[17] Almeida, F.L.A., Carvalho, R.F., Pinhal, D., Padovani, C.R., Martins, C. and Dal Pai-Silva, M. (2008) Differential Expression of Myogenic Regulatory Factor MyoD in Pacu Skeletal Muscle (Piaractus mesopotamicus Holmberg 1887: Serrasalminae, Characidae, Teleostei) during Juvenile and Adult Growth Phases. Micron, 39, 1306-1311. https://doi.org/10.1016/j.micron.2008.02.011

[18] StatSoft Inc (2005) Data Analysis Software System. Version 7.1, Tulsa.

[19] Borlogan, I.G. (1992) Dietary Requirement of Milkfish (Chanos chanos Forsskal) Juveniles for total Aromatic Amino Acids. Aquaculture, 102, 309-317. https://doi.org/10.1016/0044-8486(92)90184-M

[20] Wilson, R.P. (1989) Amino Acids and Proteins. In: Halver, J., Ed., Fish Nutrition, Academic Press, Washington DC, 111-117.

[21] Harper, A.E., Benevenga, N.J. and Wohlhueter, R.M. (1970) Effects of Ingestion of Disproportionate Amounts of Amino Acids. Physiological Reviews, 50, 428-458.

[22] Austic, R.E. (1978) Nutritional Interactions of Aminoacids. Feedstuffs, 29, 24-26.

[23] Ngamsnae, P., De Silva, S.S. and Gunasekera, R.M. (1999) Arginine and Phenylalanine Requirement of Juvenile Silver Perch Bidyanus bidyanus and Validation of the Use of Body Amino Acid Composition for Estimating Individual Amino Acid Requirements. Aquaculture Nutrition, 5, 173-180. https://doi.org/10.1046/j.1365-2095.1999.00102.x

[24] Ahmed, I. (2009) Dietary Total Aromatic Amino Acid Requirement and Tyrosine Replacement Value for Phenylalanine in Indian Major Carp: Cirrhinus mrigala (Hamilton) Fingerlings. Journal of Applied Ichthyology, 25, 719-727. https://doi.org/10.1111/j.1439-0426.2009.01284.x

[25] Borlogan, I.G. and Colosso, R.M. (1993) Requirements of Juvenile Milkfish (Chanos chanos Forsskal) for Essential Amino Acids. The Journal of Nutrition, 123, 125-132.

[26] Woynarovich, E. (1993) Manual de piscicultura. CODEVASF, Brasília.

[27] Zaminham, M. (2013) Desempenho e resposta hematológica de tilápias do Nilo alimentadas com dietas contendo níveis crescentes de triptofano. Master's Thesis, Universidade Estadual do Oeste do Paraná, Toledo.

[28] Bomfim, M.A.D., Lanna, E.A.T., Donzele, J.L., Abreu, M.L.T.D., Ribeiro, F.B. and Quadros, 
M. (2008) Redução de proteína bruta com suplementação de aminoácidos, com base no conceito de proteína ideal, em rações para alevinos de tilápia-do-nilo. Revista Brasileira de Zootecnia, 37, 1713-1720. https://doi.org/10.1590/S1516-35982008001000001

[29] Furuya, W.M., Botaro, D., Macedo, R.D., Santos, V.D., Silva, L.C.R., Silva, T.C., Furuya, V.R.S.B. and Sales, P.J.P. (2005) Aplicação do conceito de proteína ideal para redução dos níveis de proteína em dietas para tilápia-do-nilo (Oreochromis niloticus). Revista Brasileira de Zootecnia, 34, 1433-1441. https://doi.org/10.1590/S1516-35982005000500002

[30] Rowlerson, A. and Veggetti, A. (2001) Cellular Mechanisms of Post-Embryonic Muscle Growth in Aquaculture Species. In: Johnston, I.A., Ed., Muscle Development and Growth, Academic Press, San Diego, 103-140. https://doi.org/10.1016/s1546-5098(01)18006-4

[31] Aguiar, D.H., Bock, C., Padovani, C.R. and Dal Pai-Silva, M. (2008) MyoD, Myogenin and Proliferating Cell Nuclear Antigen Expression in Growing Nile Tilapia (Oreochromis niloticus L.). Aquaculture Research, 39, 1673-1679.

[32] Johnston, I.A., Manthri, S., Alderson, R., Smart, A., Campbell, P., Nickel, D., Robertson, B., Paxton, C.G.M. and Burt, M.L. (2003) Freshwater Environment Affects Growth Rate and Muscle Fibre Recruitment in Seawater Stages of Atlantic Salmon (Salmo salar L.). The Journal of Experimental Biology, 203, 2539-2552. https://doi.org/10.1242/jeb.00262

[33] Zimmerman, A.M. and Lowery, M.S. (1999) Hyperplastic Development and Hypertrophic Growth of Muscle Fibers in the White Seabass (Atractoscion nobilis). Journal of Experimental Zoology, 284, 299-308. https://doi.org/10.1002/(SICI)1097-010X(19990801)284:3<299::AID-JEZ7>3.0.CO;2-6

[34] Aguiar, D.H., Barros, M.M., Padovani, C.R., Pezzato, L.E. and Dal Pai-Silva, M. (2005) Growth Characteristics of Skeletal Muscle Tissue in Oreochromis niloticus Larvae Fed on a Lysine Supplemented Diet. Journal of Fish Biology, 67, 1287-1298. https://doi.org/10.1111/j.1095-8649.2005.00823.x

[35] Houlihan, D.F., Pedersen, B H., Steffensen, J.F. and Brechin, J. (1995) Protein Synthesis, Growth and Energetics in Larval Herring at Different Feeding Regimes. Fish Physiology and Biochemistry, 14, 195-208. https://doi.org/10.1007/BF00004310

\section{Submit or recommend next manuscript to SCIRP and we will provide best service for you:}

Accepting pre-submission inquiries through Email, Facebook, LinkedIn, Twitter, etc. A wide selection of journals (inclusive of 9 subjects, more than 200 journals)

Providing 24-hour high-quality service

User-friendly online submission system

Fair and swift peer-review system

Efficient typesetting and proofreading procedure

Display of the result of downloads and visits, as well as the number of cited articles Maximum dissemination of your research work

Submit your manuscript at: http://papersubmission.scirp.org/

Or contact as@scirp.org 